\title{
Analisis Perbedaan Motivasi Kerja Perawat Pegawai Negeri Sipil (PNS), Perawat Badan Layanan Umum Daerah (BLUD) dan Perawat Tenaga Harian Lepas (THL) di RSUD Dr. Soedirman Kebumen Berdasarkan Teori Dua Faktor Herzberg
}

\author{
Nayang Permata Charity Ayudia ${ }^{1)}$, Abdul Choliq Hidayat ${ }^{2)}$, Zunan Setiawan $^{3)}$ \\ 1), 2), 3) Program Studi S2 Manajemen, Universitas Ahmad Dahlan, Yogyakarta \\ Email:naya.charity@gmail.com ${ }^{\text {I) }}$, hacholiq@gmail.com ${ }^{2}$, Zoonan46@gmail.com ${ }^{3)}$
}

\begin{abstract}
ABSTRAK
Penelitian ini bertujuan untuk mengetahui perbedaan motivasi kerja perawat PNS, perawat BLUD dan perawat THL di RSUD Dr. Soedirman Kebumen berdasarkan teori dua faktor Herzberg. Penelitian ini menggunakan metode kuantitatif dengan jenis penelitian deskriptif komparatif. Metode pengumpulan data melalui kuesioner dengan alat ukur skala dan teknik pengambilan sampel proporsional. Sampel yang diambil adalah 57 perawat yang terdiri dari 34 perawat PNS, 4 perawat BLUD dan 19 perawat THL di RSUD Dr. Soedirman Kebumen. Alat analisis data menggunakan uji univariat dan uji Kruskal Wallis. Hasil penelitian ini menunjukkan nilai Asymp.Sig pada indikator prestasi sebesar 0.008, pada indikator tanggung jawab sebesar 0.039, pada indikator kesempatan untuk maju 0.031 dan pada indikator gaji sebesar 0,009 lebih kecil dari nilai 0.050 hal ini menunjukkan bahwa pada indikator tersebut ada perbedaan motivasi kerja antara perawat PNS, perawat BLUD dan perawat THL. Sedangkan nilai Asymp.Sig pada indikator pengakuan sebesar 0.008 , pekerjaan sebesar 0.147, peraturan sebesar 0.734, promosi sebesar 0.434, supervisi sebesar 0.402, Hubungan interpersonal sebesar 0.443, kondisi kerja sebesar 0.138 dan keamanan kerja sebesar 0.960 lebih besar dari nilai 0.050 hal ini menunjukkan bahwa pada indikator tersebut tidak ada perbedaan motivasi kerja antara perawat PNS, perawat $B L U D$ dan perawat THL. Rerata motivasi pegawai PNS sebesar 31.84, perawat BLUD sebesar 26.25 dan perawat THL sebesar 24.50 dimana motivasi kerja perawat PNS lebih tinggi dibandingkan perawat BLUD dan perawat THL.
\end{abstract}

Kata Kunci: Motivasi, Motivasi Kerja, PNS, BLUD, THL

\section{Pendahuluan}

Rumah Sakit adalah institusi pelayanan kesehatan yang menyelenggarakan pelayanan kesehatan perorangan secara paripurna yang menyediakan pelayanan rawat inap, rawat jalan, dan gawat darurat berdasarkan Peraturan Menteri Kesehatan Republik Indonesia Nomor 4 Tahun 2018 (Pasal 1) Tentang Kewajiban Rumah Sakit dan Kewajiban Pasien. Selanjutnya pada pasal 2 disebutkan bahwa salah satu kewajiban rumah sakit yang paling utama adalah memberi pelayanan kesehatan yang aman, bermutu, antidiskriminasi, dan efektif dengan mengutamakan kepentingan pasien sesuai dengan standar pelayanan rumah sakit.

Berdasarkan UU No. 44 Tahun 2009 (pasal 2) tentang rumah sakit disebutkan rumah sakit dapat didirikan oleh pemerintah, pemerintah daerah, atau swasta. Saat ini banyaknya rumah sakit-rumah sakit yang bermunculan menyebabkan tingginys tingkat persaingan dimana tidak hanya pasien yang membutuhkan rumah sakit, tetapi rumah sakit juga yang membutuhkan pasien, salah satunya untuk memenuhi target pendapatan. Sehingga untuk bisa memenangkan kompetisi dan menarik hati pasien, maka rumah sakit harus mempunyai keunggulan dibanding rumah sakit lainnya baik dari segi sarana dan prasarana maupun dari segi kualitas pelayanannya. Namun, seringkali dalam prakteknya penyelenggaraan rumah sakit belum sesuai dengan ketentuan pelayanan. Hal ini dapat dilihat dari masih banyak konsumen yang menyampaikan keluhan dan kekecewaan terhadap pelayanan rumah sakit, baik yang disampaikan melalui media (cetak atau online) maupun keluhan melalui lembaga perlindungan konsumen seperti Yayasan Lembaga Keuangan Indonesia (YLKI). Sehingga untuk mengantisipasi minimnya keluhan pasien maka Rumah Sakit perlu memiliki SDM yang memiliki kualitas prima dalam pelayanannya.

Sumber daya manusia yang ada di rumah sakit terdiri dari: 1) Tenaga kesehatan yang meliputi medis (dokter), paramedis (perawat) dan paramedis non keperawatan yaitu apoteker, analis kesehatan, asisten apoteker, ahli gizi, fisioterapis, radiographer, perekam medis. 2) Tenaga non kesehatan yaitu bagian keuangan, administrasi, personalia, pekerja kebersihan, petugas keamanan dll.

Rumah Sakit Umum Daerah (RSUD) Dr. Soedirman merupakan rumah sakit tipe $\mathrm{C}$ yang terletak di daerah Kabupaten Kebumen yang saat ini menjadi Satuan Kerja Perangkat Daerah yang menerapkan Pola Pengelolaan Keuangan Badan Layanan Umum Daerah (PPK BLUD) sesuai pasal 52 Peraturan Menteri Dalam Negeri No. 61 Tahun 2007 tentang pedoman teknis pengelolaan keuangan badan layanan umum daerah (BLUD).

Pegawai RSUD Dr. Soedirman berjumlah 906 orang yang terdiri dari 514 orang Pegawai Negeri Sipil (PNS), 91 Pegawai Badan Layanan Umum Daerah (BLUD) dan 355 orang Tenaga Harian Lepas (THL). Jika dibedakan dari jenis ketenagaannya 491 orang adalah tenaga kesehatan dan 415 orang adalah tenaga non kesehatan.

Perawat merupakan SDM tenaga Kesehatan terbesar yang dimiliki rumah sakit dengan jumlah sebesar 287 orang atau $31,67 \%$ dari keseluruhan jumlah pegawai yang 
ada dimana yang terdiri dari 173 orang PNS, 21 orang BLUD dan 93 orang THL. Syarat penetapan jenjang karir Perawat di RSUD Dr. Soedirman disebut Perawat Klinis (PK) dari level terendah Perawat Klinis Satu (PK I) hingga level tertinggi yaitu Perawat Klinis Lima (PK V). Penetapan ini berdasarkan pada regulasi agar pengambil kebijakan memiliki dasar kuat dalam menetapkan kewenangan klinis Perawat di rumah sakit atau dilayanan kesehatan. Regulasi yang dimaksud mengacu pada Peraturan Menteri Kesehatan (PMK) Nomor 40 Tahun 2017 dan Peraturan Mentri Kesehatan (PMK) Nomor 49 Tahun 2013 tentang Komite Keperawatan.

Jabatan struktural perawat dalam sistem kepegawaian di RSUD Dr. Soedirman terdiri dari Kepala Seksi (Kasi), Kepala Ruang, Ketua Tim dan Perawat pelaksana. Kasi, Kepala Ruang, Ketua Tim dijabat oleh PNS dan BLUD sedangkan untuk THL hanya dapat menjabat sebagai perawat pelaksana. Tenaga perawat yang berstatus PNS mendapatkan imbalan dihitung berdasarkan golongan PNS, untuk BLUD berdasarkan peraturan pasal 52 Peraturan Menteri Dalam Negeri No. 61 Tahun 2007 dan imbalan untuk tenaga perawat THL imbalan diberikan didasarkan Indeks perhitungan. Dalam Undang undang No. 5 tentang Aparatur Sipil Negara (ASN) menyebutkan bahwa dalam lembaga pemerintahan termasuk rumah sakit selain PNS juga diperbolehkannya pegawai kontrak, tujuan dasarnya untuk menumbuhkan kompetisi dan budaya kinerja bagi jabatan-jabatan dalam birokrasi.

Perawat merupakan elemen yang penting dalam rumah sakit "Perawat merupakan SDM yang paling banyak berinteraksi secara langsung dengan pasien, dan secara berkesinambungan memberikan asuhan keperawatan yang komprehensif dan profesional kepada pasien. Perawat adalah orang yang senantiasa memperhatikan pasiennya (caring person) dan menghasilkan kualitas pelayanan kesehatan yang profesional dan optimal karena dengan melakukan pekerjaan secara optimal dan profesional akan dapat membantu mendorong penyembuhan kesehatan pasien melalui menjalin hubungan yang harmonis antara perawat dan pasien.” (Rolyana Ferinia Pintauli, 2016).

Perawat merupakan ujung tombak dari kualitas pelayanan kesehatan dan kunci utama dalam kepuasan pasien untuk mendapatkan pelayanan kesehatan (Hartati, 2013). Namun pada kenyataanya baik buruknya pelayanan keperawatan tidak terlepas dari motivasi perawat itu sendiri. Pelayanan menjadi hal terpenting dan memiliki pengaruh yang sangat besar dalam menentukan kualitas pelayanan kesehatan disebuah rumah sakit. Pelaksanaan pelayanan keperawatan di rumah sakit dipengaruhi oleh motivasi setiap perawat itu sendiri, dengan motivasi yang baik diharapkan dapat mendorong perawat untuk sadar akan peran dan tanggungjawabnya sehingga mampu memberikan kinerja yang semakin baik dalam pelayanan.

Penelitian-penelitian terdahulu yang berkaitan dengan motivasi kerja telah banyak dilakukan. Menurut hasil penelitian Priheti (2014) diketahui ada perbedaan motivasi kerja perawat Pegawai Negeri Sipil (PNS) dengan perawat Badan Layanan Umum Daerah (BLUD) dengan $\mathrm{P}$ value sebesar 0,000 di RSUD Kraton pekalongan sedangkan penelitian yang dilakukan oleh Wahyuni (2012) diketahui hampir tidak ada perbedaan motivasi perawat pelaksana di Rumah Sakit Bhayangkara Medan dan mayoritas perawat pelaksana memiliki kinerja yang baik. Penelitian yang dilakukan Shely Mariska (2012) semua variabel yang diteliti yaitu variabel penghargaan, pengakuan, kekuasaan, kondisi lingkungan kerja, kompensasi, supervisi, jaminan pekerjaan dan peraturan memiliki hubungan yang signifikan terhadap motivasi kerja.

Penelitian ini mengunakan teori dua faktor Herzberg. Faktor-faktor tertentu ditempat kerja diidentifikasi sebagai hygiene factors (faktor kesehatan) dan motivation factors (faktor motivasi) atau dikenal juga sebagai faktor intrinsik yaitu dorongan yang timbul dari dalam diri masing-masing yaitu prestasi, pengakuan, pekerjaan itu sendiri, tanggung jawab, kesempatan untuk maju dan faktor ekstrinsik yaitu dorongan yang datang dari luar diri atau organisasi tempat bekerja yaitu gaji, peraturan, promosi, supervisi, hubungan interpersonal, kondisi kerja, keamanan kerja.

Motivasi kerja memberikan pengaruh terhadap kinerja (Hildayanti, 2016; Anwar, 2018; Septianti, 2018; Irwana, Roswaty, \& Handayani, 2018; Khoyrun, Sutanto, \& Hidayat, 2020; Sari, 2020; J, 2020; Liana, 2020; Septiadi, Marnisah, \& Handayani, 2020). Motivasi sangat dibutuhkan bagi perawat, di mana pelayanan perawat menjadi pelayanan terpenting yang memiliki pengaruh yang besar dalam menilai kualitas pelayanan kesehatan disebuah rumah sakit dimana pelayanan kesehatan merupakan hak setiap orang yang dijamin dalam UndangUndang Dasar Negara Republik Indonesia Tahun 1945 yang harus diwujudkan dengan upaya peningkatan derajat kesehatan masyarakat yang setinggi-tingginya. Oleh karena itu dirasa perlu untuk melakukan penelitian menganalisa perbedaan motivasi kerja berdasarkan status kepegawaian di RSUD Dr. Soedirman.

\section{Metode Penelitian}

Jenis penelitian ini merupakan penelitian kuantitatif yaitu penelitian tentang data yang dikumpulkan dan dinyatakan dalam bentuk angka-angka. Obyek penelitian ini adalah motivasi kerja perawat PNS, motivasi kerja perawat BLUD dan motivasi kerja perawat THL di RSUD Dr. Soedirman Kebumen. Teknik pengumpulan data menggunakan kuesioner dengan skala likert 1 sampai 5 dengan penilaian skala sebagai berikut:

Tabel 1. Skala Likert

\begin{tabular}{llcl}
\hline $\begin{array}{l}\text { Bentuk } \\
\text { Jawaban }\end{array}$ & Simbol & $\begin{array}{l}\text { Bobot } \\
\text { Skor }\end{array}$ & Bermakna \\
\hline Sangat Tidak & STS & 1 & Sangat \\
Setuju & & & $\begin{array}{l}\text { Kurang } \\
\text { Kurang }\end{array}$ \\
Tidak Setuju & TS & 2 & Cukup \\
Ragu-Ragu & R & 3 & Baik \\
Setuju & S & 4 & Sangat Baik \\
Sangat & SS & 5 & \\
Setuju & & & \\
\hline \hline
\end{tabular}

Jumlah populasi dalam penelitian ini sebanyak 287 perawat. Menurut Arikunto (2010) sampel adalah 
sebagian atau wakil populasi yang diteliti apabila jumlah responden lebih dari 100, maka pengambilan sampel $10 \%-15 \%$ atau $20 \%-25 \%$ atau lebih. Karena populasi yang ada melebihi 100 maka pengambilan sampel dalam penelitian ini adalah sebanyak $20 \%$ dari populasi yang ada yaitu $20 \%$ X 287 perawat $=57$ perawat. Teknik pengambilan sampel menggunakan metode teknik sampling proprorsional dengan perhitungan sebagai berikut:

$\begin{array}{llllll}\text { PNS } & =\frac{173}{287} \times & 57 & =34,36 \\ \text { BLUD } & =\frac{21}{287} \times & 57= & 4,17 \\ \text { THL } & =\frac{93}{287} \times & 57= & 18,47\end{array}$

Sehingga didapatkan 57 responden penelitian yang terdiri dari 34 perawat PNS, 5 perawat BLUD dan 19 perawat THL. Alat analisis data dilakukan menggunakan uji univariat dan uji Kruskal Wallis.

\section{Hasil Penelitian dan Pembahasan \\ Hasil}

Uji univariat

Tabel 2, 3 dan 4 menunjukkan hasil pengujian dengan menggunakan uji univariat untuk motivasi kerja perawat PNS, perawat BLUD dan perawat THL. Indikator motivasi kerja diukur berdasarkan teori dua faktor Herzberg berupa kebutuhan intrinsik yaitu prestasi, pengakuan, pekerjaan itu sendiri, tanggung jawab, kesempatan untuk maju dan kebutuhan ekstrinsik yaitu gaji, peraturan, promosi, supervisi, hubungan interpersonal, kondisi kerja, keamanan kerja. Tanggapan dari responden terhadap pernyataan-pernyataan pada kuesioner dapat dideskripsikan sebagai berikut:

Tabel 2. Motivasi Kerja Perawat PNS

\begin{tabular}{|c|c|c|}
\hline \multirow[b]{2}{*}{ Indikator } & \multicolumn{2}{|c|}{ PNS } \\
\hline & Mean & Bermakna \\
\hline Prestasi & 4.08 & Baik \\
\hline Pengakuan & 3.90 & Cukup \\
\hline $\begin{array}{l}\text { Pekerjaan itu } \\
\text { sendiri }\end{array}$ & 4.16 & Baik \\
\hline Tanggungjawab & 4.11 & Baik \\
\hline $\begin{array}{l}\text { Kesempatan } \\
\text { untuk maju }\end{array}$ & 4.00 & Baik \\
\hline Gaji & 3.94 & Cukup \\
\hline Peraturan & 3.94 & Cukup \\
\hline Promosi & 3.67 & Cukup \\
\hline Supervisi & 3.95 & Cukup \\
\hline Hubungan & 3.90 & Cukup \\
\hline Interpersonal & & \\
\hline Kondisi Kerja & 3.77 & Cukup \\
\hline Keamanan kerja & 3.92 & Cukup \\
\hline
\end{tabular}

Sumber : Olah Data 2019

Berdasarkan tabel 2 dapat diketahui sebagian persepsi responden perawat PNS pada indikator pekerjaan itu sendiri sebesar 4.16 dan mean sebesar 4.11 pada indikator tanggung jawab, hal ini menggambarkan bahwa perawat PNS sebagian besar memiliki motivasi yang baik terhadap indikator tanggung jawab dan pekerjaan itu sendiri.

Tabel 3. Motivasi Kerja Perawat BLUD

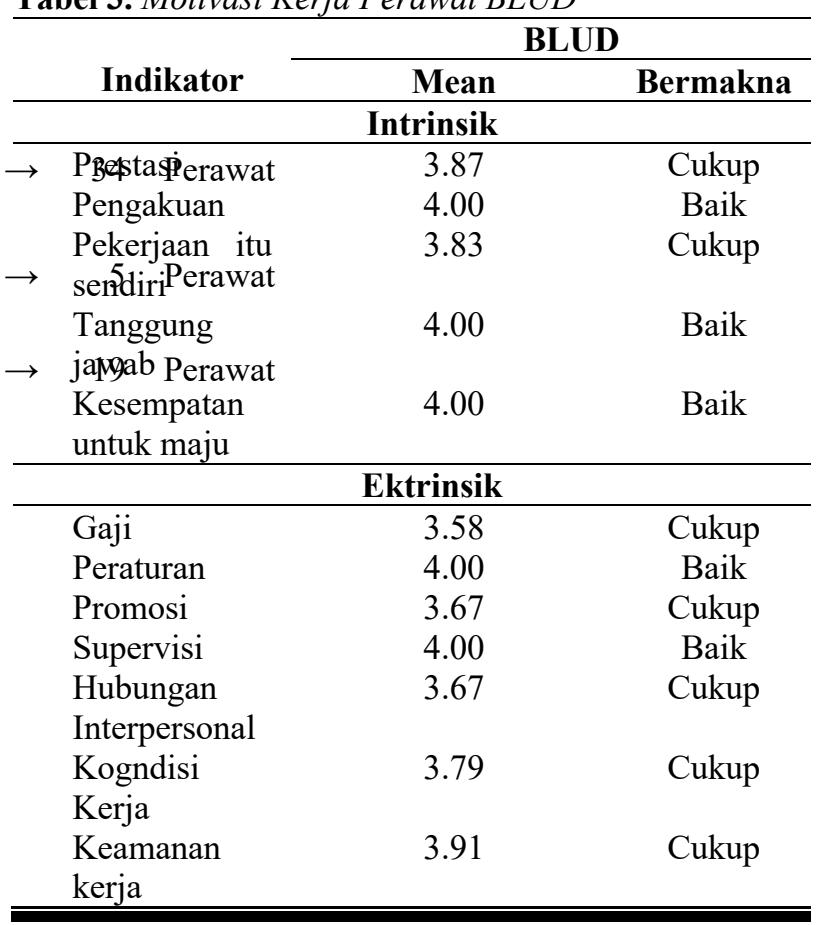

Sumber : Olah Data 2019

Berdasarkan tabel 3 dapat diketahui sebagian persepsi responden perawat BLUD memiliki nilai mean 4.00 pada indikator pengakuan, tanggung jawab, pengakuan sebesar 4.00 dan mean sebesar 4.11 pada indikator tanggung jawab, kesempatan untuk maju, peraturan dan supervisi. hal ini menggambarkan bahwa pada indikator-indikator tersebut perawat BLUD memiliki motivasi yang baik.

Tabel 4. Motivasi Kerja Perawat THL

\begin{tabular}{lcc}
\hline \multirow{2}{*}{ Indikator } & \multicolumn{2}{c}{ THL } \\
\cline { 2 - 3 } & Mean & Bermakna \\
\hline Prestasi & 3.93 & Cukup \\
Pengakuan & 3.83 & Cukup \\
Pekerjaan itu & 4.07 & Baik \\
sendiri & & \\
Tanggung & 4.00 & Baik \\
jawab & & \\
Kesempatan & 3.82 & Cukup \\
untuk maju & & \\
& & \\
\hline Gaji & Ekstrinsik & Cukup \\
Peraturan & 3.54 & Cukup \\
Promosi & 3.91 & Cukup \\
Supervisi & 3.57 & Baik \\
Hubungan & 4.04 & Cukup \\
Interpersonal & 3.79 &
\end{tabular}




\begin{tabular}{lcc} 
Kondisi & 3.99 & Cukup \\
$\begin{array}{l}\text { Kerja } \\
\text { Keamanan } \\
\text { kerja }\end{array}$ & 3.94 & Cukup \\
\hline
\end{tabular}

Sumber: Olah Data 2019

Berdasarkan tabel 4 dapat diketahui sebagian persepsi responden perawat THL pada indikator pekerjaan itu sendiri sebesar 4.07 dan mean sebesar 4.04 pada indikator supervisi, hal ini menggambarkan bahwa perawat PNS sebagian besar memiliki motivasi yang baik terhadap indikator pekerjaan itu sendiri dan supervisi.

Tabel 5. Motivasi Kerja Perawat RSUD Dr. Soedirman

\begin{tabular}{ll}
\hline \multicolumn{1}{c}{ Status Pegawai } & Mean \\
\hline Perawat PNS & 31.84 \\
Perawat BLUD & 26.25 \\
Perawat THL & 24.50 \\
\hline TOTAL & $\mathbf{2 7 . 5 3}$ \\
\hline \hline
\end{tabular}

Sumber : Olah Data 2019

Berdasarkan tabel 5 Nilai rata-rata (mean) pada perawat PNS adalah sebesar 31.84, pada perawat BLUD sebesar 26.25 dan perawat THL sebesar 24.50. Hasil penelitian ini menunjukkan bahwa tingkat rata-rata motivasi kerja pada perawat PNS lebih besar dibandingkan perawat BLUD dan perawat THL.

\section{Uji Kruskal Wallis}

Uji kruskal wallis digunakan untuk menguji apalah ada perbedaan untuk lebih dari dua kelompok dengan hasil sebagai berikut:

Tabel 6. Perbedaan Motivasi Kerja Perawat PNS, BLUD dan $T H L$

\begin{tabular}{lcc}
\hline \multicolumn{1}{c}{ Indikator } & Hasil & Keterangan \\
\hline Prestasi & 0,008 & Ada \\
Pengakuan & 0,356 & Tidak \\
Pekerjaan & 0,147 & Tidak \\
Tanggung jawab & 0,039 & Ada \\
Kesempatan & 0,031 & Ada \\
untuk maju & & \\
\hline & Ektrinsik & \\
\hline Gaji & 0,009 & Ada \\
Peraturan & 0,734 & Tidak \\
Promosi & 0,434 & Tidak \\
Supervisi & 0,402 & Tidak \\
Hubungan & 0,443 & Tidak \\
Interpersonal & & \\
Kondisi Kerja & 0,138 & Tidak \\
Keamanan Kerja & 0,960 & Tidak \\
\hline \hline
\end{tabular}

Sumber: Olah Data 2019

Berdasarkan hasil analisa yang sudah dilakukan menggunakan uji Kruskal Wallis pada tabel 6 maka diperoleh hasil bahwa terdapat perbedaan motivasi kerja antara perawat PNS, perawat BLUD dan perawat THL pada beberapa indikator yaitu prestasi dengan nilai
Asymp.Sig sebesar 0.008, tanggung jawab dengan nilai Asymp.Sig sebesar 0.039, kesempatan untuk maju dengan nilai Asymp.Sig sebesar 0.031, Gaji dengan nilai Asymp.Sig sebesar 0.009 dimana pada keempat indikator tersebut nilai Asymp.Sig $<0.050$.

Sedangkan untuk indikator pengakuan dengan nilai Asymp. Sig sebesar 0.356, pekerjaan itu sendiri dengan nilai Asymp.Sig 0.147, peraturan dengan nilai Asymp.Sig sebesar 0.734, promosi dengan nilai Asymp.Sig sebesar 0.434, hubungan interpersonal dengan nilai Asymp.Sig sebesar 0.443, kondisi kerja dengan nilai Asymp.Sig sebesar 0.138, keamanan kerja dengan dengan nilai Asymp.Sig sebesar 0.960 diperoleh hasil nilai Asymp.Sig $>0.05$ sehingga tidak terdapat perbedaan pada indikatorindikator tersebut.

\section{Pembahasan}

Berdasarkan hasil penelitian jika dikaitkan dengan teori dua faktor menurut Herzberg yang membagi teori menjadi dua faktor yaitu Hygiene Factors dan Motivation Factors dimana bila faktor-faktor ini dipenuhi akan memberikan rasa puas terhadap karyawan namun apabila tidak terpenuhi akan mengakibatkan rasa ketidakpuasan maka hasil penelitian menunjukkan seluruh indikator terpenuhi yaitu prestasi, pengakuan, pekerjaan itu sendiri, tanggungjawab, kesempatan untuk maju, gaji, peraturan, promosi, supervisi, hubungan interpersonal, kondisi kerja dan keamanan kerja. Hal ini terlihat pada tingginya nilai masing masing indikator yang diteliti. Hasil penelitian ini juga menunjukkan perawat yang bekerja di RSUD Dr. Soedirman merasa motivasi kerja yang selama ini diberikan rumah sakit telah dinilai baik dan indikatorindikator tersebut memiliki peranan penting bagi perawat untuk memotivasi diri dalam bekerja memberikan pelayanan keperawatan kepada pasien. Hal ini sesuai dengan Edy Sutrisno (2011) yang menyatakan bahwa faktor-faktor yang mempengaruhi motivasi kerja seseorang meliputi keinginan untuk meperoleh penghargaan, kekuasaan, kondisi lingkungan tempat bekerja, kompensasi yang diterima, kegiatan supervisi, jaminan pekerjaan yang diberikan serta peraturan atau kebijakan yang berlaku.

Dari rerata didapatkan hasil motivasi kerja perawat PNS lebih tinggi dibandingkan dengan perawat BLUD dan perawat THL. Hasil penelitian ini sejalan dengan penelitian yang dilakukan Haryanti (2019) dimana tingkat motivasi kerja PNS lebih besar dibandingkan motivasi kerja pegawai BLUD. Hasil penelitian ini tidak sejalan dengan penelitian yang dilakukan Nurhayati dan Laksmiwati (2013) yang menyatakan bahwa terdapat adanya perbedaan motivasi antara karyawan tetap dan karyawan kontrak, dimana motivasi karyawan kontrak lebih tinggi dibandingkan dengan karyawan tetap.

Setelah dilakukan analisa data dengan menggunakan uji kruskal walls diketahui bahwa terdapat perbedaan motivasi kerja antara perawat PNS, perawat BLUD dan perawat THL untuk indikator prestasi, tanggung jawab, kesempatan untuk maju dan gaji. Sementara untuk indikator pekerjaan itu sendiri, peraturan, promosi, hubungan interpersonal, kondisi kerja dan keamanan 
kerja tidak terdapat perbedaan motivasi kerja perawat PNS, perawat BLUD dan perawat THL. Hasil penelitian ini sejalan dengan penelitian yang dilakukan Gumilang (2018) yang menyatakan bahwa terdapat perbedaan motivasi kerja pegawai puskesmas BLUD dan non BLUD pada indikator kebutuhan fisik dan indikator kebutuhan akan status, sedangkan kebutuhan sosial dan kebutuhan atas realisasi diri tidak ada perbedaan. Pada penelitian yang dilakukan oleh Ardani (2015) yang menyatakan bahwa terdapat perbedaan motivasi kerja antara pegawai tetap dan pegawai tidak tetap. Arif (2012) terdapat perbedaan motivasi kerja antara karyawan kontrak dan karyawan tetap.

\section{Penutup}

Kesimpulan

Berdasarkan hasil penelitian dapat disimpulkan:

1. Terpenuhi teori motivasi dua faktor menurut Herzberg untuk seluruh indikator yang diteliti yaitu prestasi, pengakuan, pekerjaan itu sendiri, tanggung jawab, kesempatan untuk maju, gaji, peraturan, promosi, supervisi, hubungan interpersonal, kondisi kerja dan keamanan kerja baik untuk perawat PNS, perawat BLUD dan perawat THL dengan skor ratarata mean terendah 3.57 dan tertinggi 4.16 dengan klasifikasi kategori cukup dan baik.

2. Gambaran Motivasi kerja perawat PNS memperlihatkan motivasi kerja yang baik yaitu dengan skor rata-rata yang diberikan terhadap seluruh pernyataan indikator motivasi kerja sebesar 31.84

3. Gambaran Motivasi kerja perawat BLUD memperlihatkan motivasi kerja yang baik yaitu dengan skor rata-rata yang diberikan terhadap seluruh pernyataan indikator motivasi kerja sebesar 26.25

4. Gambaran Motivasi kerja perawat THL memperlihatkan motivasi kerja yang baik yaitu dengan skor rata-rata yang diberikan terhadap seluruh pernyataan indikator motivasi kerja sebesar 24.50

5. Motivasi keja perawat PNS lebih tinggi dibandingkan dengan perawat BLUD dan perawat THL.

6. Terdapat perbedaan motivasi kerja perawat PNS, perawat BLUD dan perawat THL untuk indikator prestasi, tanggung jawab, kesempatan untuk maju dan gaji. Tidak terdapat perbedaan motivasi kerja perawat PNS, perawat BLUD dan perawat THL untuk indikator pekerjaan itu sendiri, peraturan, promosi, hubungan interpersonal, kondisi kerja dan keamanan kerja.

\section{Saran}

Motivasi kerja perawat PNS, perawat BLUD dan perawat THL dinilai baik untuk seluruh indikator namun untuk meningkatkan motivasi menjadi lebih baik lagi rumah sakit dapat melakukan beberapa hal diantaranya pihak rumah sakit dapat memberikan pendekatan lain selain gaji seperti reward, kompensasi dan lainnya tanpa membedakan status pegawai baik PNS, BLUD maupun THL, diberikannya pelatihan tambahan untuk meningkatkan keahlian dari perawat dan diadakannya kegiatan yang bisa menigkatkan keakraban dengan harapan agar tercipta mencipatakan kondisi dan hubungan kerja yang nyaman.

\section{Daftar Pustaka}

Ardani, E. Perbedaan Motivasi Kerja Antara Pegawai Tetap dengan Pegawai Tidak Tetap pada Hotel The Royal Surakarta Heritage Solo. Skripsi Program Studi Psikologi Fakultas Psikologi Universitas Muhammadiyah, Surakarta.

Arif, P. F. Perbedaan Motivasi Kerja Antara Karyawan Kontrak dan Karyawan Tetap pada PT. Bank Rakyat Indonesia Cabang Cimahi. Psympathic. Jurnal Ilmiah Psikologi Desember 2012, Vol. V, No.2:566=581. Fakultas Psikologi UIN Sunan Gunung Djati. Bandung.

Arikunto. S. 2010. Prosedur Penelitan Suatu Pendekatan Praktek. PT. Rineka Cipta. Jakarta.

Edy, Sutrisno. 2011. Manajemen Sumber Daya Manusia, Cetakan Ketiga, Kencana Prenada Media Group, Jakarta.

Gumilang, A. A., Mahanggoro, P. T., Aini, Qurrotul. 2018: 111-120. Motivasi dan Kepuasan Kerja Pegawai Puskesmas BLUD dan non-BLUD Kabupaten Semarang. Health Sciences and Pharmacy Journal Vol.2,No. 3, Desember 2018, pp. 11-120. Semarang.

Hartati, 2013. Gambaran Kinerja Perawat Dalam Pelaksanaan Asuhan Keperawatan Di Instalasi Rawat Inap Lontara RSUP Dr. Wahidin Sudirohusodo. Skripsi. Program S1 Fakultas Kesehatan Masyarakat Universitas Hasanudin. Makassar.

Haryanti, Atika. 2019. Perbedaan Tingkat Motivasi Kerja Antara Pegawai Negeri Sipil Dan Pegawai Badan Layanan Umum Daerah (BLUD). Skripsi. Program Studi Psikologi Fakultas Psikologi Universitas Muhammadiyah, Surakarta.

Hildayanti, S. K. (2016). Analisis Regresi Pengaruh Kepuasan Kerja dan Motivasi terhadap Kinerja Dosen Universitas Indo Global Mandiri Palembang. Jurnal Ilmiah Ekonomi Global Masa Kini, 7(1), 1926.

Irwana, M. R., Roswaty, R., \& Handayani, S. (2018). Pengaruh Motivasi terhadap Kinerja Pegawai pada Dinas Perhubungan Kota Palembang UPTD Balai Pengujian Kendaraan Bermotor. Jurnal Ilmiah Ekonomi Global Masa Kini, 8(2), 42-46.

J., C. K. M. (2020). Employees Work Motivation and Its Effect on their Performance. International Journal of Community Service \& Engagement, 1(01), 39-43. Retrieved from http://journal.jisinstitute.org/index.php/ijcse/article/view/72

Khoyrun, H., Sutanto, A., \& Hidayat, A. C. (2020). Pengaruh Kompetensi, Motivasi, dan Lingkungan Kerja terhadap Kinerja Dosen Perguruan Tinggi 
Swasta Daerah Istimewa Yogyakarta. Jurnal Ilmiah Ekonomi Global Masa Kini, 11(1).

Liana, W. (2020). Pengaruh Motivasi terhadap Produktivitas Karyawan PT Telkom Indonesia, Tbk Cabang Palembang. Jurnal Nasional Manajemen Pemasaran \& SDM, 1(01), 65-72. https://doi.org/10.47747/jnmpsdm.v1i01.25

Mariska, Shelly. 2012. Studi Tentang Motivasi Kerja Pegawai Non Medis Di Rumah Sakit Umum Pusat Fatmawati Jakarta, Skripsi. Program Sarjana Kesehatan Masyarakat Peminatan Manajemen Rumah Sakit Fakultas Universitas Indonesia, Jakarta.

Nurhayati, Y., \& Laksmiwati, H. 2013. Perbedaaan Tingkat Motivasi Berprestasi Antara Karyawan Kontrak Dan Karyawan Tetap di Bank Panin KCU Cokelat Surabaya. Character, 1-7. Surabaya.

Priheti, Hernik. 2014. Perbedaan Motivasi Kerja Perawat Pegawai Negeri Sipil (PNS) Dengan Perawat Kontrak Badan Layanan Umum Daerah (BLUD) Di RSUD Kraton Pekalongan. Skripsi. Program Studi Keperawatan Fakultas Ilmu Keperawatan Dan Kesehatan Universitas muhammadiyah. Semarang.

Republik Indonesia. 2007. Peraturan Menteri Dalam Negeri No. 61 Tahun 2007 tentang Pedoman Teknis Pengelolaan Keuangan Badan Layanan Umum Daerah. Menteri Dalam Negeri Republik Indonesia. Jakarta.

Republik Indonesia. 2009. Undang Undang Republik Indonesia Nomor 44 Tahun 2009 tentang Rumah Sakit. Presiden Republik Indonesia. Jakarta

Republik Indonesia. 2014. Undang Undang No. 5 Tahun 2014 tentang Aparatur Sipil Negara. Presiden Republik Indonesia. Jakarta.

Republik Indonesia. 2018. Peraturan Menteri Kesehatan Republik Indonesia Nomor 4 Tahun 2018 tentang Kewajiban Rumah Sakit dan Kewajiban Pasien. Menteri Kesehatan Republik Indonesia. Jakarta.

Republik Indonesia. 2017. Peraturan Menteri Kesehatan Republik Indonesia Nomor 40 Tahun 2017 tentang Pengembangan Jenjang Profesional Perawat Klinis. Menteri Kesehatan Republik Indonesia. Jakarta.

Rolyana, Ferinia Pintauli, 2016. Kepribadian, Motivasi Kerja, Hubungan Antar Karyawan, Keterikatan Karyawan. Serta Pengaruhnya. Disertasi. Sekolah Pasca Sarjana Ilmu Manajemen Universitas Pendidikan Indonesia, Bandung.

Sari, Y. K. (2020). Pengaruh Motivasi terhadap Semangat Kerja Pegawai pada Kantor Balai Diklat Keuangan Palembang. Jurnal Nasional Manajemen Pemasaran \& SDM, 1(01), 54-64. https://doi.org/10.47747/jnmpsdm.v1i01.8

Septiadi, M. D., Marnisah, L., \& Handayani, S. (2020). Pengaruh Motivasi terhadap Kinerja Karyawan PT Brawijaya Utama Palembang. Jurnal Nasional Manajemen Pemasaran \& SDM, 1(01), 38-44. https://doi.org/10.47747/jnmpsdm.v1i01.5

Septianti, D. (2018). Pengaruh Kemampuan Kerja dan Motivasi Ekstrinsik Terhadap Kinerja Karyawan
Pada CV. Pesona Palembang. Jurnal Ilmiah Ekonomi Global Masa Kini, 9(1), 38-46.

Wahyuni, Isra. 2012 Motivasi Kinerja Perawat Pelaksana di Rumah Sakit Bhayangkara Medan. Skripsi. Program S1 Fakultas Keperawatan. Universitas Sumatera Utara. Medan. 